\title{
Effect of D-penicillamine on serum immunoglobulins and rheumatoid factor
}

\author{
RODNEY BLUESTONE AND LEONARD S. GOLDBERG \\ From the Wadsworth VA Hospital, Los Angeles, 90073, and the Department of Medicine, \\ UCLA School of Medicine, Los Angeles, 90024, U.S.A.
}

Penicillamine has been used in the treatment of patients with rheumatoid arthritis with variable clinical response (Jaffe, 1963; Camus, Guillien, Crouzet, Schaeffer, and Lièvre, 1970; Zuckner, Ramsey, Dorner, and Gantner, 1970; Golding, Wilson, and Day, 1970). Moreover, observations on the effect of this drug on serum immunoglobulins and rheumatoid factor titres have yielded conflicting and indefinite results (Jaffe, 1970). Currently, a U.K. multi-centre, double-blind, controlled trial is under way in which D-penicillamine is being compared to a placebo amongst patients with definite or classical rheumatoid arthritis (Camp, 1971). A definitive paper reporting that trial will include detailed results of changes in rheumatoid factor titres measured in another laboratory. The present study reports the effect of the active drug versus placebo on the serum immunoglobulins and rheumatoid factor titres over a 6-month period in a group of patients entered into the current trial.

\section{Material and methods}

PATIENT GROUP

Sera from patients were obtained immediately before therapy and approximately 3 and 6 months after continuous penicillamine or placebo treatment. Patients were coded so that all assays were performed without knowing whether a patient was on drug or placebo*. The dosage schedule was usually designed gradually to achieve oral doses of $1,500 \mathrm{mg}$. of active penicillamine per day by the 9th week of treatment, and to maintain that dose thereafter. However, one patient was still taking the lower initial dose at the 3- and 6-month intervals.

SEROLOGICAL TESTS

Rheumatoid factor and quantitation of serum immunoglobulins were determined on pre-treatment, and on 3- and 6-monthly samples simultaneously.

Accepted for publication April 13, 1972.

* Sera kindly supplied by Dr. F. M. Andrews (Royal Berkshire Hospital, Reading); Dr. Virginia Camp (Nuffield Orthopaedic Centre, Oxford); Dr. D. N. Golding (Princess Alexandra Hospital, Harlow) Dr. J. R. Golding (Royal Bath Hospital, Harrogate); and Dr. A. G. S. Hill (Stoke Mandeville Hospital, Aylesbury).
Serum immunoglobulin levels were determined by radial immunodiffusion in agar-antibody plates (Hyland Laboratories, Los Angeles, California). Normal values ( \pm 2 standard deviations) for adults in our laboratory were:

IgG 1,090 mg. per $100 \mathrm{ml} .( \pm 490)$;

IgA $190 \mathrm{mg}$. per $100 \mathrm{ml} .( \pm 140)$;

IgM 130 mg. per $100 \mathrm{ml} .( \pm 90)$.

Tests for rheumatoid factor activity were performed after initial heat inactivation at $56^{\circ} \mathrm{C}$. for $30 \mathrm{~min}$.; activityo was measured at $22^{\circ} \mathrm{C}$. using latex particles coated with aggregated human gamma globulin and sheep red bloo cells sensitized with rabbit gamma globulin. Heterophi? antibody titres were determined using a 2 per cent. suspension of non-sensitized sheep erthrocytes. Known positive and negative controls were included in each assay. Latex-agglutination titres greater than $1: 40$ and nonheterophil sensitized sheep-cell titres greater than $1: 2$ were considered abnormal.

\section{Results}

Serum immunoglobulins (Table I)

The majority of patients in the trial showed hypergammaglobulinaemia with elevated levels of $\mathrm{IgG}_{3} \mathrm{~A}$, and $\mathbf{M}$. Individual serum IgG levels in patients taking penicillamine were lower at 3 months, and by 6 months the change had reached statistical significance (Table II; $\mathrm{P}<0.05$ ). No such fall in serum IgG was apparent in placebo-treated patients. By chance, the patients treated with penicillamine had a higher mean pre-treatment level of IgG than the control group. This prevented a significant difference in IgG levels between the two groups at 6 months despite the definite fall in serum IgG amongst the drug-treated patients by that time (Table II). There was no apparent effect of the drug on serum IgA levels (Table III).

Drug-treated patients had a marked reduction $(P<0.02)$ in serum IgM at 3 months, well sustained at 6 months in contrast to controls whose IgM levels did not fall (Table IV). Comparison of the penicillamine group with the controls showed that there was 
Table I Immunoglobulin levels and rheumatoid factor titres in patients receiving D-penicillamine or placebo

\begin{tabular}{|c|c|c|c|c|c|c|c|c|c|c|c|c|c|c|c|c|c|}
\hline \multirow{2}{*}{$\begin{array}{l}\text { Patient } \\
\text { No. }\end{array}$} & \multicolumn{5}{|c|}{ Pre-treatment } & \multicolumn{6}{|c|}{ At 3 months } & \multicolumn{6}{|c|}{ At 6 months } \\
\hline & $I g G^{*}$ & $\operatorname{Ig} A^{*}$ & $\operatorname{Ig} M$ & $L t \dagger$ & $S S C \ddagger$ & Dose§ & $\operatorname{Ig} G$ & $\operatorname{Ig} A$ & $\operatorname{Ig} M$ & $L T$ & $S S C$ & Dose & $\operatorname{Ig} G$ & $\operatorname{Ig} A$ & $\operatorname{Ig} M$ & $L T$ & $S S C$ \\
\hline 1 & 2,500 & 580 & 130 & 320 & 8 & 1500 & 2,000 & 550 & 48 & 80 & 1 & - & - & - & - & & \\
\hline 2 & 8,300 & 350 & 320 & 320 & 64 & 1500 & - & $\overline{0}$ & - & - & - & 1500 & 1,550 & 360 & 142 & 160 & 128 \\
\hline 3 & 1,290 & 235 & 107 & 640 & 16 & 1500 & 1,290 & 203 & 60 & 160 & 16 & 1500 & 1,440 & 192 & 39 & 80 & 16 \\
\hline 4 & 4,400 & 1,120 & 334 & 640 & 2 & 1500 & 2,500 & 870 & 182 & 640 & 2 & 1500 & 2,000 & 1,050 & 146 & 640 & 4 \\
\hline 5 & 740 & 340 & 83 & 320 & 4 & 1500 & 360 & 64 & 30 & 80 & 8 & 1500 & - & & & & \\
\hline 6 & 1,220 & 490 & 400 & 320 & 32 & 1500 & - & - & 一 & - & - & 1500 & 590 & 420 & 88 & 40 & 16 \\
\hline 7 & 8,330 & 46 & 110 & 640 & 128 & 1500 & 1,770 & 460 & 62 & 640 & 128 & 1500 & 1,540 & 930 & 50 & 640 & 512 \\
\hline 8 & 1,290 & 325 & 48 & 160 & 8 & 1500 & 2,000 & 396 & 60 & 80 & 4 & 1500 & 1,140 & 396 & 48 & 160 & 2 \\
\hline 9 & 1,370 & 250 & 100 & 80 & 4 & 1500 & 880 & 286 & 44 & 20 & 4 & 1500 & 1,440 & 250 & 75 & 80 & 1 \\
\hline 10 & 7,300 & 1,160 & 320 & 160 & 2 & 250 & $\overline{0}$ & $\overline{10}$ & $\overline{a n}$ & - & - & 250 & 1,370 & 590 & 88 & 20 & 4 \\
\hline 1 & & 170 & 182 & 640 & 4 & $\mathbf{P}$ & 2,800 & 130 & 204 & 640 & 4 & $\mathbf{P}$ & 2,250 & 122 & 163 & 640 & 4 \\
\hline 2 & 2,450 & 450 & 120 & 640 & 16 & $\mathbf{P}$ & 1,750 & 450 & 130 & 640 & 8 & $\mathbf{P}$ & 2,250 & 420 & 107 & 640 & 16 \\
\hline 3 & 1,800 & 550 & 204 & 1,280 & - & $\mathbf{P}$ & 200 & 450 & 107 & 640 & 8 & $\mathbf{P}$ & 1,800 & 580 & 104 & 640 & 4 \\
\hline 4 & 1,540 & 450 & 206 & 160 & 8 & $\mathbf{P}$ & 1,260 & 400 & 206 & 160 & 8 & $\mathbf{P}$ & 3,140 & 450 & 226 & 160 & 2 \\
\hline & 5,800 & 880 & 400 & - & - & $\mathbf{P}$ & 9,300 & 148 & 360 & 80 & 8 & $\mathbf{P}$ & 10,000 & 158 & 400 & 80 & 8 \\
\hline 6 & 3,900 & 550 & 107 & 320 & 32 & $\mathbf{P}$ & 一 & - & - & 一 & - & $\mathbf{P}$ & 2,500 & 510 & 130 & 640 & 32 \\
\hline & & 250 & 97 & 640 & 4 & $\mathbf{P}$ & 一 & - & - & - & - & $\mathbf{P}$ & 2,500 & & 130 & 640 & 128 \\
\hline & & 630 & 180 & 1,280 & 8 & $\mathbf{P}$ & - & - & - & - & - & $\mathbf{P}$ & 2,150 & 590 & 140 & 1,280 & 4 \\
\hline
\end{tabular}

* mg. per $100 \mathrm{ml}$.

† Latex-agglutination $\}$ titres expressed as reciprocal of the highest serum dilution giving a positive test.

¥ Sensitized sheep cell

mg. active
$\mathbf{P}=$ placebo.

Table II Effect of penicillamine on serum IgG

\begin{tabular}{|c|c|c|c|}
\hline \multirow[t]{2}{*}{ Group } & \multicolumn{3}{|c|}{ Serum IgG (mg. per cent.; mean \pm S.E.) } \\
\hline & Pre-treatment & At 3 months & At 6 months \\
\hline $\begin{array}{l}\text { Penicill- } \\
\text { amine (10) }\end{array}$ & $3,674 \pm 997$ & $1,543 \pm 280$ & $1,421 \pm 137$ \\
\hline Controls (8) & $2,917 \pm 534$ & $3,062 \pm 1,615$ & $53,324 \pm 963$ \\
\hline
\end{tabular}

Table III Effect of penicillamine on serum $\operatorname{Ig} A$

\begin{tabular}{|c|c|c|c|}
\hline \multirow[t]{2}{*}{ Group } & \multicolumn{3}{|c|}{ Serum IgA (mg. per cent.; mean \pm S.E.) } \\
\hline & Pre-treatment & At 3 months & At 6 months \\
\hline $\begin{array}{l}\text { Penicill- } \\
\text { amine (10) }\end{array}$ & $531 \pm 107$ & $404 \pm 99$ & $523 \pm 111$ \\
\hline Controls (8) & $491 \pm 78$ & $315 \pm 73$ & $383 \pm 66$ \\
\hline
\end{tabular}

No significant changes in serum IgA occurred in either group.

a statistically significant difference in IgM levels present at 3 and 6 months (Table IV; $P<0.05$ ).

\section{Rheumatoid factor titres}

The penicillamine-treated patients showed a median fall of 1.5 tubes in their latex-agglutination titres during 6 months... in other words, half the patient's titres fell by two or more tubes. In four the titre remained unchanged, but in no instance did it rise. This represents a statistically significant change (Wilcoxon signed-rank test; $\mathbf{P}=\mathbf{0 . 0 1 6}$ in a one-sided
Table IV Effect of penicillamine on serum IgM

\begin{tabular}{|c|c|c|c|}
\hline \multirow[t]{2}{*}{ Group } & \multicolumn{3}{|c|}{ Serum IgM (mg. per cent.; mean \pm S.E.) } \\
\hline & Pre-treatment & At 3 months & At 6 months \\
\hline $\begin{array}{l}\text { Penicill- } \\
\text { amine (10) }\end{array}$ & $195 \pm 41$ & $69 \pm 19$ & $84 \pm 14$ \\
\hline Controls (8) & $187 \pm 34$ & $201 \pm 44$ & $175 \pm 35$ \\
\hline
\end{tabular}

Paired data analysis of IgM change within the penicillamine-treated group showed significant reduction at 3 months $(t=3.2747 ; P<0.02)$ and at 6 months $(\mathrm{t}=3.3946 ; \mathrm{P}<0.02)$

The difference between penicillamine-treated and control groups was significant at 3 months $(t=-2.7338 ; P<0.05)$ and at 6 months $(t=-2 \cdot 3928 ; P<0.05)$.

test). There was a highly significant correlation between the decline in serum IgM levels and the fall in latex titre after 6 months of penicillamine treatment (Spearman rank correlation co-efficient, $Y_{\mathrm{S}}=0.897$; $\mathbf{P}<0.001$ in a one-sided test). By Fisher's exact test, and regarding only a two-tube fall in latex titre as meaningful, it was apparent that a fall in titre was associated with a reduction of serum IgG to 40 per cent. of pre-treatment levels $(P=0.008)$. There was no significant change in sheep cell agglutination titres in either group of patients.

\section{Discussion}

This study has demonstrated that penicillamine therapy results in a significant fall in serum IgG and IgM levels, present after 3 months but more marked at 6 months. No drug effect was detected on IgA levels, and placebo-treated patients exhibited no 
significant change in serum IgG, A, or M levels. The penicillamine-treated patients showed a significant fall in rheumatoid factor titre, which was manifest by the latex-agglutination test only. This fall was associated with a reduction of serum $\operatorname{IgM}$ to 40 per cent. of pre-treatment levels.

Previous reports on the effect of penicillamine on serum immunoglobulins and rheumatoid factor have been variable. Most observers have detected a probable drug-induced diminution in the levels of serum IgG and IgM and in the titres of antiglobulin (Jaffe, 1963, 1970; Goldberg and Barnett, 1970), although a recent study failed to confirm this (Zuckner and others, 1970). However, no double-blind control trial adequately to study this effect on meaningful numbers of patients has previously been reported; nor has a selective effect of penicillamine on serum IgG and IgM been previously ascertained. Goldberg and Barnett (1970) noted a pronounced diminution of IgG and IgM in their patient with essential cryoglobulinaemia, with less effect on the level of $\operatorname{IgA}$. In our patients a lack of drug effect on serum IgA levels was striking.

The mechanism by which penicillamine causes a reduction in serum immunoglobulins is unknown. In vitro the drug acts by disruption of interchain disulphide bonds of macroglobulins, although a variable effect of the drug on IgG and IgA has been noted (Virella and Lopes-Virella, 1970). However, it is unlikely that the activity of this drug in vitro accounts for its effects in vivo, and it is probable that other, unknown, mechanisms lower serum immunoglobulin levels. The results of this study suggest that the immunosuppressive action of penicillamine is a central one-selecting those cells which produce only certain classes of heavy chain.

The relationship between drug dose and immunosuppression has been partly elucidated by this study. Significant lowering of IgG and IgM levels was apparent at 3 months. By this time most patients were taking $1,500 \mathrm{mg}$. of drug daily and this dose had not been achieved until the 9th week of treatment. Moreover, Patient 10 never achieved doses higher than $250 \mathrm{mg}$ /day yet showed substantial falls in IgG and IgM levels. It is therefore likely that relatively small doses of continuous penicillamine may produce this effect. It would be interesting to know what immune suppression the drug might exert in patients with Wilson's disease or cystinuria, where smaller doses suffice and pre-treatment immunoglobulin levels are presumably not elevated as in rheumatoid disease.

It remains to be seen if penicillamine is a useful drug for treating rheumatoid arthritis. Nevertheless, a chemical which selectively suppresses certain immune aberrations characterizing the rheumatoid state should stimulate much interest.

\section{Summary}

Administration of penicillamine (in doses of up to $1,500 \mathrm{mg}$./day) to patients with rheumatoid arthritis resulted in a significant lowering of serum IgG and IgM levels. No such effect was detected on IgA levels, nor did placebo administration affect the serum immunoglobulins in a control group of patients Lowering of the serum IgM level to below 40 per cent of the pre-treatment value was associated with significant fall in latex-agglutination titre, but not of sheep cell titre. It seems likely that penicillamine exerts at least part of its immunosuppressive effect at a cellular level.

We thank Dr. W. H. Lyle (Dista Products Ltd.) for coordinating the serum samples, coding, and dosage details. Dr. David Champion kindly advised on the statistical interpretations of the results. Miss G. Davies provided valuable technical assistance.

RB was supported by a grant from the Arthritis and Rheumatism Council of Great Britain, U.S.P.H.S. Grant No. GM 15759, and an Institutional Support Grant from theSouthern California Chapter, The Arthritis Foundation.

\section{References}

CAMP, A. V. (1971) Abstracts of VII European Rheumatology Congress, 41.17 (Preliminary report of a controlled trial of penicillamine in rheumatoid arthritis)

Camus, J. P., Guillien, P., Crouzet, J., Schaeffer, A., ANd Lièvre, J. A. (1970) Ann. Méd. intern., 121, 237 (Pénicillamine et polyarthrite rhumatoide)

GoldBerg, L. S., AND BARNETT, E. V. (1970) Arch. intern. Med., 125, 145 (Essential cryoglobulinemia; Immunologic studies before and after penicillamine therapy)

Golding, J. R., WILSON, J. V., AND DAY, A. T. (1970) Postgrad. med. J., 46 [October], 599 (Observations on the trea tment of rheumatoid disease with penicillamine)

JAFFE, I. A. (1963) Ann. rheum. Dis., 22, 71 ( Comparison of the effects of plasmapheresis and penicillamine on the level of circulating rheumatoid factor) (1970) Arthr. and Rheum., 13, 436 (The treatment of rheumatoid arthritis and necrotizing vasculitis with penicillamine)

Virella, G., AND Lopes-Virella, M. F. (1970) Clin. exp. Immunol., 7, 85 (Effects of therapeutically usefuls thiols (DL-penicillamine and $a$-mercaptopropionyl-glycine) on immunoglobulins)

ZuCKNER, J., RAMSEY, R. H., DORNER, R. W., AND GANTNER, G. E. (1970) Arthr. and Rheum., 13, 131 (Dpenicillamine in rheumatoid arthritis) 